\title{
パルス電磁誘導法と高周波法による メタン放電と薄膜析出
}

$\begin{array}{llllll}\text { 正 員 蛯 } & \text { 原 } & \text { 健 } & \text { 治 } & \text { (熊本大) } \\ \text { 准 員 } & \text { 相 } & \text { 良 } & \text { 一 } & \text { 郎 } & \text { (熊本大) } \\ \text { 准 員 大 } & \text { 平 } & & \text { 尚 } & \text { (熊本大) } \\ \text { 正 員 } & \text { 前 } & \text { 田 } & \text { 定 } & \text { 男 } & \text { (熊本大) }\end{array}$

\section{1. まえがき}

アモルファスシリコン (a-Si) やアモルファスカー ボン (a-C) などの薄膜の作製には各種放電形式（直 流，交流，高周波，マイクロ波など）を用いて気体を 分解する方法が工業的雇く用いられている。しか し，超 LSI，太晹電池，光メモリーなどの電子材料や 絶緣性，耐熱性，耐摩耗性を有する新索材としててれ らの薄膜を利用するには，使用目的に適した電気的，

光学的, 機械的, 熱的特性を有する薄膜を作製するた めに，膜特性と作製条件との関係を解明することが必 要である。すなわち，放電形式，ガス湿合比，ガス圧 力, 供給電力, 基板材料, 基板温度などの条件を変え ることにより，プラズマ中の電子エネルギー分布や分 解・電離過程 および基板の膜析出・成長過程を制御 し，最適なアモルファス膜を作製する条件を明らかに するととが重要である。

メタン気体の解離・電離プロセスは Winters 氏(1) や Aarts 氏ら ${ }^{(2)}$ による電子ビーム衝突励起法（Electron impact method) や Braun 氏らによるスパーク 放電法 ${ }^{(3)}$ によって調べられており，また，高周波放電プ ラズマの解離・電離プロセスは Duval 氏らのベンゼ ンについての実験(4)がある。しかし，プラズマの電子 温度や非平衡性と a-C 膜成長・構造との関係ははと

Methane Dischages and Thin Film Deposition by a Pulsed Electromagnetic Inductive Method and a Radio-Frequency Method. By Kenji Ebihara, Member, Ichiro Sagara, Associate, Hisashi Oohira, Associate \& Sadao Maeda, Member (Department of Electrical Engineering and Computer Science, Faculty of Engineering, Kumamoto University).

蛇原健治 : 正員, 据本大学工学部電気情報工学科

相良一郎 : 准員, 热本大学工学部電気情報工学科

大平 尚 : 准員, 热本大学工学部筙気情報工学科

前田定男 : 正員, 撨本大学工学部電毁情報工学科

んど報告されておらず，小林氏らの膜成長速度と $\mathrm{CH}$ ， $\mathrm{H}$ 種から放射されるスペクトル比との関係が最近報告 されている程度である(5)。

本研究においてはパルス電磁誘導プラズマ法と，高 周波プラズマ法によるメタン放電プラズマ特性わよび 両方法によるアモルファスカーボン膜の析出について 報告する。メタンプラズマからの放射光の分光学的測 定をむとにして，メタン気体の非平衡性と電子温度な どを導出し，パルス電磁誘導放電と高周波放電の特性 を比較・検傠した。また, 両放電によるアモルファス カーボン膜の基板への析出状態や膜質特性などの特異 性についてす考察した。その結果, 電子温度と析出膜 の光学ギャップとの相関が部分的ながら解明できた。

パルス放電方式に上る材料生成は有電極放電による Sokolowski 氏らの報告があるが(6)(7), 本諭文のよう な無電極放電を利用した例は見られない。

\section{2. 実験装置}

$\langle 2 \cdot 1\rangle$ 高周波プラズマ CVD 装置 高周波プラ ズマ CVD 装置は容量結合形で，ステンレス放電管 $(\phi 20 \mathrm{~cm} \times 50 \mathrm{~cm})$ からなり，他励式高周波発振器（日 本高周波(株)，RF-010 D 型， $13.56 \mathrm{MHz}, 1 \mathrm{~kW}$ ) 加 らの電力を放電管軸に垂直に置かれた電極に供給し た。との放電管内を拡散ポンプ，ロータリーポンプに より $10^{-6}$ Torr の基底真空度まで排気した後, $\mathrm{CH}_{4}$ ガスを導入した。気体圧力は絶対圧マノメータ (MKS Baratoron 222 BA 型), ガス流量はマスフローコン トローラ（スタンダードテクノロジ社, SEC-421) K よって測定した。a-C 膜析出のための基板にはアルミ ニウム板とスライドガラスを用い，電極の表面に固定 したてれらの基板をヒータによって $200^{\circ} \mathrm{C}$ に加熱し 


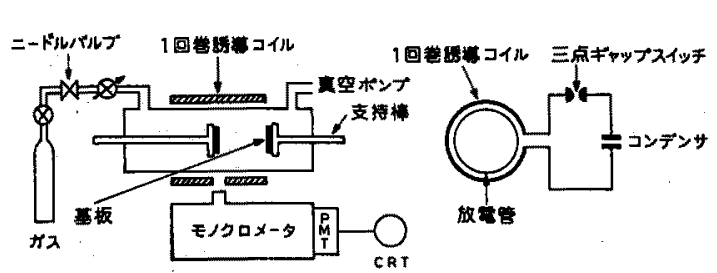

図 1 パルス電磁誘導プラズマ CVD 装置

Fig. 1. Schematic of a pulsed electromagnetic inductive plasma CVD system.

た。

〈2.2〉パルス電磁誘導プラズマ CVD パルス電 磁誘導プラズマCVD 装置を目1亿示す。コンデンサ C を充電した徭、ギャップスイッチを通して1回巻 コイルにパルス電流 $I_{G}$ を流すと，放電管軸方向の磁 束密度 $B z$ が時間变化するために, 角度方向に 誘導 電界 $E_{\theta}$ が発生する。放電管の中心軸上り半径 $r$ での 誘導電界の大きさ $E_{\theta}(r)$ は

$$
E_{\theta}(r)=-\frac{1}{2 \pi r} \frac{d}{d t}\left(\int_{0}^{r} B_{z}(a) 2 \pi a d a\right) \ldots \ldots
$$

である。こてで $a$ は変数である。

高周波電界が归加されると放電管内の気体が $\mathrm{E}$ 放電 (静電的放電) やH放電 (電磁腾導的放電) ${ }^{(8)}$ によって 解離, 的起, 電離し、このプラズマには誘導電流

$$
J_{\theta}(r)=-\frac{1}{\mu_{0}} \frac{\partial B_{z}(r)}{\partial r}
$$

が流れ，その結果， $J_{\theta}(r) \times B z(r)$ による電磁力がプラ

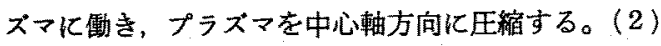
式において $\mu_{0}$ は真空の透磁率 $\left(=4 \pi \times 10^{-7} \mathrm{H} / \mathrm{m}\right)$ で ある。

本研究で使用したパルス電磁誘導放電プラズマ CVD の諸特性を表 1 に示す。

メタン気体 (100\%) を適当な圧力まで綮入した後， 三点ギャップスイッチを始動して，パルスメタンプラ ズマを発生した。膜析出のための基板をコイル中央部

表 1 パルス電磁誘導プラズマCVD 装置 の動作条件

Table 1. Operating conditions of the pulsed

\begin{tabular}{|c|c|}
\hline \multicolumn{2}{|c|}{ 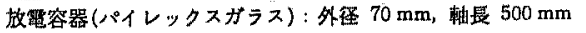 } \\
\hline コンデンサバンク C & $: 6 \mu \mathrm{F}$ \\
\hline 充 電 籍 正 & $: 25 \mathrm{kV}(1.9 \mathrm{~kJ})$ \\
\hline コイル電流 & 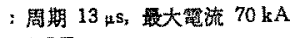 \\
\hline 股大磁束密度 & $: 0.5 \mathrm{~T}$ \\
\hline 㿞大角度方向電界 & $: 2.0 \mathrm{kV} / \mathrm{m}$ \\
\hline 使用気 体 & $\mathrm{CH}(100 \%)$ \\
\hline 矮在力 & : $5 \sim 100 \mathrm{mTorr}$ \\
\hline 與体湤 賈 & $: 10 \sim 20 \mathrm{sccm}$ \\
\hline
\end{tabular}
inductive plasma CVD system.
とコイル端部に放電管軸と垂直に置いた。繰返し放電 (時間間げき的 1 分) によって基板上に薄膜が析出す るととが認められた。

生成プラズマの特性を明らかにするために，両プラ ズマについて分光学的測定を行った。図 1 亿示すよう にプラズマからの放射光を分光器 $(1 \mathrm{~m}, 0.5 \mathrm{~m}, 0.25$ $\mathrm{m} モ$ クロロータ）によって分析し，相対強度比法を 用いて電子温度などを求め, 析出膜との関係を調へ た。

\section{3. 実験結果と検討}

〈3・1〉メタンの放電特性 高周波プラズマCVD によるカーボン薄膜生成時の放電パラメータとして, 一般には高周波電力が用いられている。時間平均され た単位体積あたりの高周波電力は $\frac{n_{e} e^{2} E_{0}{ }^{2}}{2 m \nu_{m}}\left(\frac{\nu_{m}^{2}}{\nu_{m}^{2}+\omega^{2}}\right)$ で 表される。

ここで $E_{0}$ : 高周波電界波高值， $\omega$ : 角周波数, $n_{\mathrm{e}}$ : 電子密度, $\nu_{m}$ : 㣫突周波数, $e$ : 電子ゆ電荷量, $m:$ 電 子質量。従って，材料プロセシングに招いて放電制御， 膜析出時の表面現象などを考察するには電界強度 $E_{0}$ む重要なパラメータになる。

メタンガス $(100 \%)$ の放電開始電圧特性を使用 し た高周波ブラズマCVD 装置について図2に示す。

$V_{s}$ は放電開始電圧, $p$ は気体压力, $d(=10 \mathrm{~cm}$, $13 \mathrm{~cm}$ ) は電極間距離である。電極には真ちゅうの円 板電極 (直径 $40 \mathrm{~mm}$ ) を用いた。パイレックス放電管 を用いた直流の放電開始特性も比較のために示した。

高周波電界 $E_{0} e^{i \omega t}$ の場においてイオンあるいは電 子の移動する距離 $2 \mu E_{0} / \omega （ \mu$ : イオンあるいは電子 の移動度）が電極間距離 $d$ より小さい場合に，正イオ ンや電子が電極間に捕獲される。との荷電粒子の残留

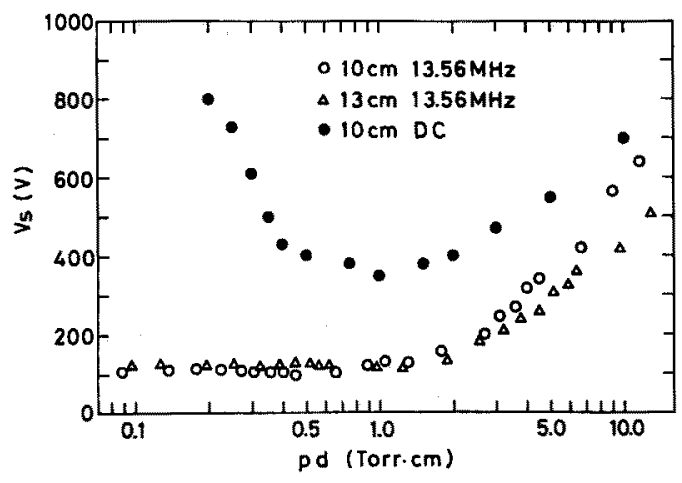

図 2 ×タン気体の絶縁破壊特性

Fig. 2. Electric breakdown characteristics of methane gas. 
効果が図 2 の高周波の放電開始電圧が直流に比べて低 下している一つの理由である。また，高周波放電の pd の低い領域で $V$ s が $100 \mathrm{~V}$ の一定值になっている のは，pd が低いとてろでは電極間放電上り，片側の 電極とステンレス容器壁との間で放電か甡ずるためで ある。

本実験ではステンレス壁との放電ができるだけ減じ られるような pd $(0.2 \sim 1.0$ Torr $\cdot \mathrm{cm})$ および電極間 電圧 $(30 \sim 400 \mathrm{~V})$ の条件を選んで持続放電を発生し; 膜析出を行った。

図 3 は $50 \mathrm{~m}$ Torr, $20 \mathrm{~W}$, 電極間電质 $60 \mathrm{~V}$, 電極間 距離 $d=5 \mathrm{~cm}$ の条件におりる高周波メタンプラズマ からの放射光スペクトルである。 $\lambda=430 \mathrm{~nm}$ 付近の強 いスペクトルは $\mathrm{CH}$ ラジカルの $A^{2} \Delta-X^{2} I$ 遷移によ るものであり， $\mathrm{CH}(\mathrm{A})$ 準位への励起には $14.6 \mathrm{eV} の$ エネルギーが必要であることが実験的に報告されてい る(2)。 $\mathrm{CH}_{4}$ の份解によってH原子加生成され，H（主 量子数 $n=3), \mathrm{H}(n=4), \mathrm{H}(n=5)$ の励起原子加らの 遷移により, $\mathrm{H} \alpha(656.3 \mathrm{~nm}), \mathrm{H} \beta(486.1 \mathrm{~nm}), \mathrm{H} \gamma$ $(434.1 \mathrm{~nm})$ のバルマー系列スペクトルが放射され る(図 3)。乙れらのバルマー系列のスペクトルの放 射のためには $21.9 \pm 0.5(\mathrm{H} \alpha), 21.8 \pm 0.5(\mathrm{H} \beta)$, $22.3 \pm 0.5(\mathrm{H} \gamma) \mathrm{eV}$ のエネルギーがそれぞれ必要で ある。

$\mathrm{CH}\left(A^{2} \Delta-X^{2} I\right)$ の $431.5 \mathrm{~nm}$ ¿ $\mathrm{H} \alpha(656.3 \mathrm{~nm})$ のスペクトル強度比は放電条件（電力, 気体圧力など） により変化した。小林氏らは一定高周波電力 $(100 \mathrm{~W})$ にて $1 \mathrm{~m}$ Torr 20 m Torr の代力筙囲ではガス圧力の 增加に伴いスペクトル比 $\mathrm{CH}$ (431.5)/H $\alpha(656.3)$ は 単調に增加するととを報告している(5)。本実験ではこ

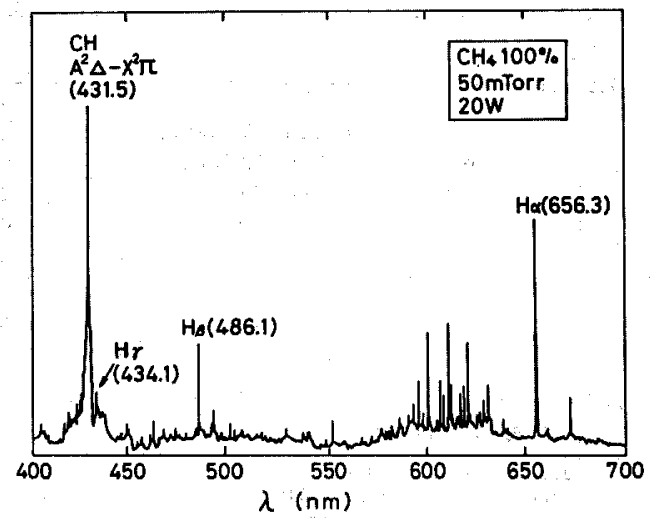

図 3 高周波メタンプラズマからの放射光 スペクトル

Fig. 3. Optical emission spectrum obtained from an rf methane plasma.

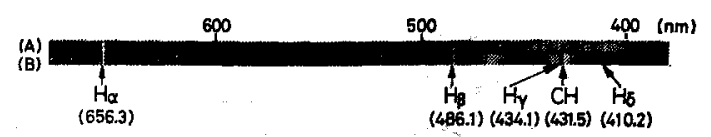

図 4 パルス電磁誘莩メタンプラズマの スペクトル写真. $25 \mathrm{~m}$ Torr.

Fig. 4. Spectrogram of pulsed inductive methane plasmas at $25 \mathrm{~m}$ Torr.

の比は, $10 \mathrm{~W} \sim 40 \mathrm{~W}$ の出力変化に対して, $30 \mathrm{mT}$ orr では $0.3 \sim 0.5,100 \mathrm{~m}$ Torr においては $1.0 \sim 1.5$ と なった。これは王力堌加に伴う H原子の増加に比し て， $\mathrm{CH}$ ラジカルが著しく增加しているためであるて とがわかった。王力や電力の変化に伴う図 3 のスペク トル線強度の性質については〈3.2〉節で電子温度と 関連つりて考察する。

パルス電磁誘導放電によって生成したメタンプラズ マの分光写真を図 4 (B) に示す。玏力 25 mTorr で生 成されたプラズマの中央部からの発光スペクトルであ り，40回の繰返し放電によって露光したものである。 との放電形式では $\mathrm{CH}$ ラジカルからの $A^{2} \Delta-X^{2} I I$ 僄 移によるスペクトルに比較して, $\mathrm{H} \alpha, \mathrm{H} \beta, \mathrm{H} \gamma$ のス ペクトルが強く観湘された。眼中上部（A）のHのスペ クトルは波長同定に使用した水素スペクトル放電によ るあのである。以上の結果より，パルス電磁誘導放電 に拈いては高周波放電より高いエネルギー準位 $(\mathrm{H} \gamma$ や $\mathrm{H} \delta$ など）が選択的に励起されている瞬間がおるこ とが明らかである。図 5 は $\mathrm{H} \alpha, \mathrm{H} \beta, \mathrm{H} \gamma$ スペクトル 強度の時間変化を示したものである。

使用した光電子增倍管は R446 (浜松), 光学検出系

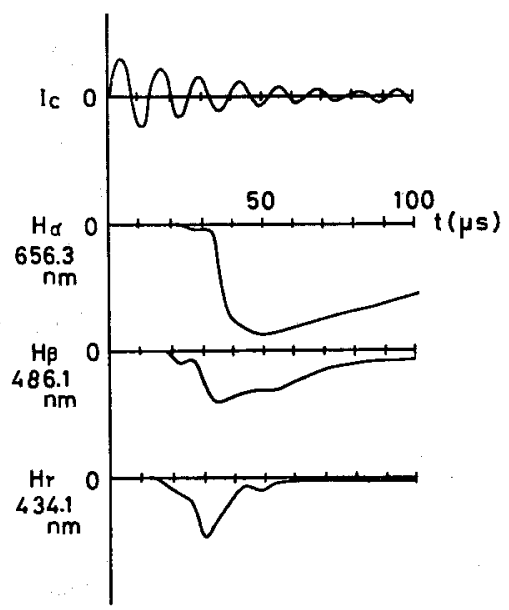

図 5 水素パルマー系列のスペクトル強度の 時間変化メタン压力. $15 \mathrm{~m}$ Torr.

Fig. 5. Time-resolved emission spectrum of Balmer radiation at $15 \mathrm{mT}$ Torr. 
全体の時間応答特性は $5 \mathrm{~ns}$ 以下である。スペクトル 線は電流の第二周期より観測され， $t=30 \sim 40 \mu \mathrm{s}$ 付近 でピークになり，約 $100 \mu \mathrm{s}$ 継続した。

〈3.2〉電子温度と非平衡性”プラズマ放射光の スペクトル線強度から粒子（原子，分子，イオン）の 动起状態や電子温度を予想することができる。一般に 波長 $\lambda$ の線スペクトル強度 $I$ は, Boltzmann 分布を 仮定すると，

$$
I=K g \frac{A}{\lambda} \exp \left(-\frac{E}{k T}\right)
$$

となる。

ここて， $g:$ 統計的重み， $A:$ 遷移確率， $E$ :

上準位の励起エネルギー, $T$ : 電子温度, $k$ :

Boltzmann の定数, $K:$ 定数,

因 6 は $\mathrm{H} \alpha, \mathrm{H} \beta, \mathrm{H} \gamma$ のスペクトル線強度の測定值か ら求まる值 $\log (I \lambda / K g A)$ を $E$ 比対してプロットし たあのである。洌定されたスペクトル線強度は NBS タングステンランプによって感度補正を行っており，

また,,$\odot A の$ 值は Dresvin の文献(9)より引用した。 これらの実験データが直線で記述できるならば，その 傾きから電子温度を求めるここができる。

$E$ を $[\mathrm{eV}], T$ を(K)とするならば傾きは $(-5,040 /$ T) である。図6 は高周波放笔電力 $10 \mathrm{~W}$ 時の結果で いずれあ実験デー夕は直線上にほほ並んでいるので, エネルギー分布は Boltzmann 分布に近いと見なされ

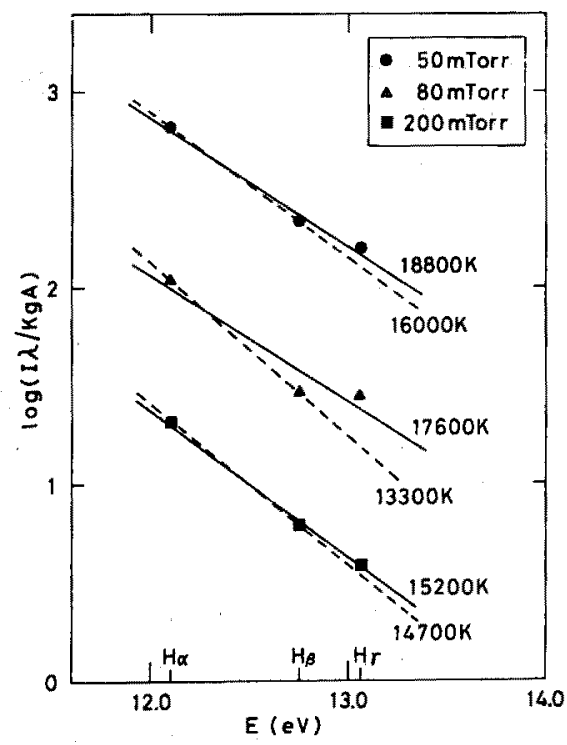

因 6 高周波プラズマの電子温度 高周波電力 $10 \mathrm{~W}$.

Fig. 6. Excitation temperature of $\mathrm{rf}$ plasmas at $10 \mathrm{~W}$.

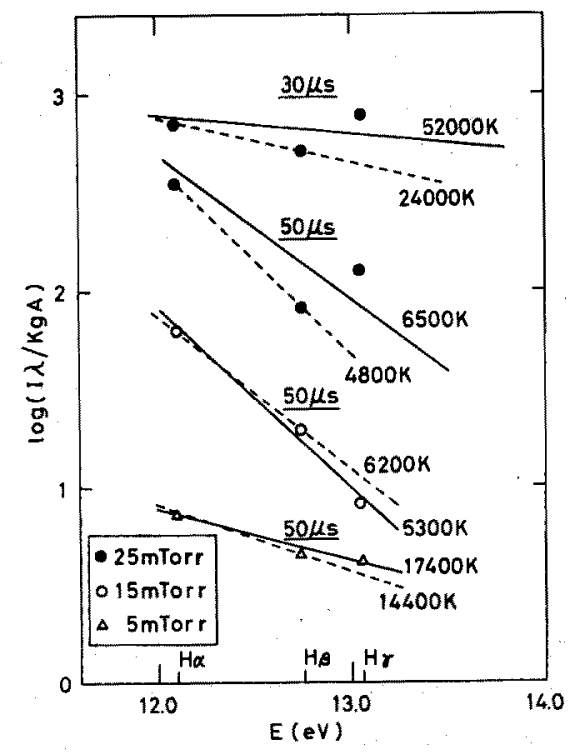

図 7 パルス電磁誘導プラズマの非平衡性

Fig. 7. Nonequilibrium of pulsed inductive plasmas.

る。傾きから求められる䉓子温度は $50 \mathrm{~m}$ Torr のとき $18,800 \mathrm{~K}, 80 \mathrm{~m}$ Torr のとき $17,600 \mathrm{~K}, 200 \mathrm{mTorr}$ で は $15,200 \mathrm{~K}$ になっている。

同梯の方法で計測したバルス電磁誘導放電プラズマ の結果を図 7 亿示す。 $\mathrm{H} \alpha, \mathrm{H} \beta, \mathrm{H} \gamma$ の3本のスペク ト儿線加求めた電子温度 (寒線) と $\mathrm{H} \alpha, \mathrm{H} \beta$ の值 から求めた温度（破線）では $30 \mu \mathrm{s}$ で差異が顕著であ る。乙れは粒子密度のエネルギ一分布が Boltzmann 分布になっていないととを示している。との非平衡性 は主にパルス電磁界による $n=5$ 準位への励起が放電

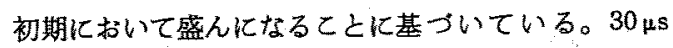
に怙りる温度は $20,000 \sim 50,000 \mathrm{~K}$ の程度であり図 6 に示した高周波放電の電子温度より高くなっている。

$30 \mu \mathrm{s}$ 付近では笔磁力が有效仁作用し，プラズマ柱 が磁気的に圧縮され，プラズマ加熱されるために高温

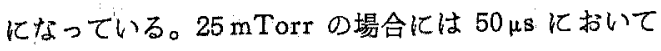
もまだ非平衡ブラズマ状態にあるととがわかる。しか

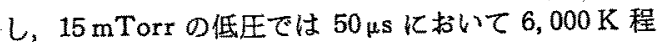
度の平衡プラズマになっているととが図 7 に示されて いる。

また， $5 \mathrm{mT}$ Torr の放電では $50 \mu \mathrm{s}$ で $17,400 \mathrm{~K} \sim$ $14,400 \mathrm{~K}$ の電子温度になっている。この条件では, 20 付近でスペクトル強度が急激に立ち上がり最高 になり $(\sim 30,000 \mathrm{~K})$, 発光牥約 $50 \mu \mathrm{s}$ 継続 L, 図 5 の放電より時間的に早く消隇するととが観測された。 以上からコイル電流の周期 $13 \mu \mathrm{s}$ のパルス放電は動 
作压力によって放電継䊦時間，電子温度の時間変化， プラズマ柱体積が異なるととが明らがなった。また 圧力によっては $\mathrm{H} \gamma$ や $\mathrm{H} \delta$ などの高いエネルギー準 位を選択的に励起することも可能である。（1)式より $E_{\theta}(r)$ は電流の角周波数に比例しているから、コイル 電流の周期を小さくするととにより $E_{\theta}(r)$ を增加する ことができる。従って，コイル電流の周期を変化させ， $E_{\theta}(r)$ ．の周期を変化させるととにより，プラズマの電 子エネルギー分布を制御して，気体の特定のエネル ギー準位を選択的に励起できるととが予想される。更 に，高周波定常放電（図 3) で $600 \mathrm{~nm}$ 付近に生じる スペクトル（主に $\mathrm{H}_{2}$ による発光と思われる）が, パ ルス放電（図 4) ではほとんと観測されないととは良 質の膜形成を阻害する不純物や，他のラジカル種の発 生を㧕制するととが可能であるととを示している。

〈3・3〉 高周波プラズマ CVD によるアモルファス カーボン膜析出と膜特性蒿周波放電による膜析出 速度はメタン封入壬力 $30 \sim 100 \mathrm{mT}$ orr, 供給電力 10 〜 $40 \mathrm{~W}$ の範囲で $1.0 \sim 2.8 \mathrm{~nm} / \mathrm{min}$ であった。常温 スライド基板に生成された膜は長時間放置後に篭が 生じ，良質の膜は得られなかったために基板を加熱し た。300 C゙らいに加熱すると条件によっては析出膜 のグラファイト化が起こると言われており，本実験で はこの温度以下の $200^{\circ} \mathrm{C}$ に保った。その結果, 基板

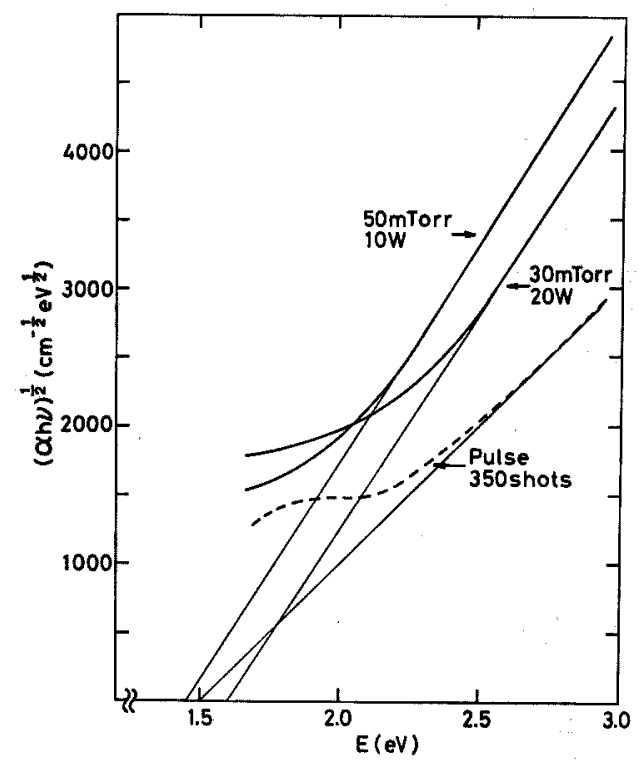

図 8 高周波法（実線）とパルス電磁誘導法 （破線）に上る析出膜の吸収係数

Fig. 8. Absorption coefficient of thin films deposited by rf dischrges (solid line) and the pulsed inductive discharge (broken line).
表 2 電子温度と光学ギャップの関係

Table 2. Relationship between electron temperature and optical gap energy.

\begin{tabular}{|c|c|c|c|c|c|}
\hline サンプル & $\underset{\text { (mTorr) }}{\text { 压 }}$ & 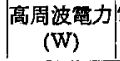 & 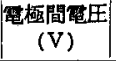 & $\begin{array}{c}\text { 要子温度 } \\
(\mathrm{K})^{*}\end{array}$ & $\begin{array}{c}\text { 光学ギ+ップ } \\
(\mathrm{eV})\end{array}$ \\
\hline A & 30 & 10 & 30 & 12,300 & 1.50 \\
\hline B & 30 & 20 & 40 & 13,000 & 1.60 \\
\hline c & 50 & 10 & 50 & 16,000 & 1.45 \\
\hline D & 100 & 10 & 32 & 15,500 & 1.64 \\
\hline
\end{tabular}

*暨子温度は $\mathrm{H} \alpha, \mathrm{H} \beta$ より等出した。

への密着性が良くなった。

可視吸収スペクトルの実験值をもとにして得られた $(\alpha h \nu)^{1 / 2}$ と光エネルギー $E$ との関係を図 8 に示す。 ここで $\alpha$ は吸収係数， $h$ はプランク定数，vは光の振 動数である。30 mTorr, $20 \mathrm{~W}$ の条件で作成した膜 は光学ギャップ $E_{\mathrm{opt}} \approx 1.6 \mathrm{eV}$ であるのに対し，50 mTorr, 10 W の条件では $E_{\text {opt }} \approx 1.45 \mathrm{eV}$ の小さい値 になった。相対強度比法によれば，前者のプラズマの 電子温度 ( $\mathrm{H} \alpha, \mathrm{H} \beta$ より求めた值) は $13,000 \mathrm{~K}$ であ るのに対して，後者の電子温度は $16,000 \mathrm{~K}$ であっ た。同一電力では図6に見られるように王力が上昇す るにつれて電子温度が低下するという一般的傾向があ るが，電力の供給されているプラズマ体積は電力，圧 力によって変化し，また，小電力では放電の局所的集 中などが生ずるために上述のような温度が得られたす の上思われる。表 2 は 4 個のサンプルの作製条件，電 子温度および生成 $\mathrm{a}-\mathrm{C}: \mathrm{H}$ 膜の光学ギャップの関係 を示したものである。但し，電子温度は $\mathrm{H} \alpha, \mathrm{H} \beta$ の 2 本のスペクトル線の強度比より求めた值である。10 $\mathrm{W}$ の電力で $30 \mathrm{~m}$ Torr, $50 \mathrm{~m}$ Torr の放電は外見上類 似のプラズマ発光特性（発光色，電極周辺の発光領域 なよ゙）を示すが，100 mTorr では局所的な放電が生 じ, 発光色す $30 \mathrm{mTorr}, 50 \mathrm{~m}$ Torr の場合とは異なっ た。表 2 より光学ギャップと電子温度の明確な依存 性を見いだすまでには至らないが, $12,300 \mathrm{~K}$ から $16,000 \mathrm{~K}$ の電子温度のプラズマによって 1.45〜1.64 $\mathrm{eV}$ の光学ギャップを有する薄膜が生成されることは わかる。

Bubenzer 氏ら(10)ゃDischler 氏ら(11) は $2.3 \mathrm{MHz}$ の高周波故電プラズマ CVD において $\mathrm{a}-\mathrm{C}: \mathrm{H}$ 膜を 析出し，その生成膜の $E_{\text {opt }}$ が $0.8 \mathrm{eV}-1.8 \mathrm{eV}$ ，範 目にあるととを示し，水素含有量が增えると $E_{\text {opt }}$ が 増加することを報告している。Anderson 氏(12)は高 周波グロー放電によって $\mathrm{a}-\mathrm{C}: \mathrm{H}$ 膜を作成し，基板 温度 $(400 \mathrm{~K}-650 \mathrm{~K})$ によって $E_{\text {opt }}$ 加変化し, $400 \mathrm{~K}$ では $E_{\text {opt }}=2.6 \mathrm{eV}$ であるが $650 \mathrm{~K}$ になると $E_{\text {opt }}=$ $1.5 \mathrm{eV}$ 亿低下することを報告している。との $E_{\text {opt }}$ 低 
下の主は理由は温度上昇に伴いグラファイト領域が增 大するためであると思われている。プラズマの電子温 度は高周波電力(高周波電圧), 気体圧力の主パラメー 夕に支配される。しかし，電子温度とメタン分解によ って生ずる水素原子, 水素イオン, 他のラジカル種の 粒子密度との関係やプラズマによる基板加熱効果につ いては未知の部分が多い。 Mackowski 氏らは a-C : $\mathrm{H}$ 膜成長表面層の温度はプラズマから供給されるエネ ルギーによって支配されており，低電力（単位電極面 皘あたり $0.1 \sim 1 \mathrm{~W})$ においてさえ表面は $350^{\circ} \mathrm{C}$ 近く まで加熱されるととを述べている(13)。すなわち，電 子温度の上昇は結果として，電子衝突による成長膜表 面の温度の上昇に寄与すると思わ机る。表 2 のサンプ ル C (16,000 K) そおいて $E_{\mathrm{opt}}$ が 1.45 の小さい值に なっているのは上述のような電極表面への高エネル ギー電子衝突による局所的なグラファイト化や水素含 有量の変化によるあのと思われる。

図 8 の 2 個のサンプル表面に平行アルミニウム電極 を真空蒸着法によって付着し，両電極間（電極間げき $1 \mathrm{~mm}$ ）の抵抗の温度変化を実測し，それをむとにし た導電率の温度依存性から活性化エネルギー $\left(E_{a}\right)$ を 求めた。 $50 \mathrm{mTorr}, 10 \mathrm{~W}, 60$ 分で作製した膜では $E_{a}=0.75 \mathrm{eV}, 30 \mathrm{mTorr}, 20 \mathrm{~W}, 60$ 分で作製した膜 では $E_{a}=0.84 \mathrm{eV}$ の值が得られ，それぞれ $E_{\mathrm{opt}}$ の約 半分に等しいととが明らかになった。とのととはフェ ルミ準位がエネルギーギャップのほぼ中間に位置して いることを示している。次に $\mathrm{KBr}$ 基板上に $\mathrm{a}-\mathrm{C}: \mathrm{H}$ 膜 $(50 \mathrm{mTorr}, 10 \mathrm{~W}$, 膜厚 $200 \mathrm{~nm})$ を析出し，その赤 外吸収スペクトルを測定したが，500〜 3, $000 \mathrm{~cm}^{-1}$ の 笧囲では特定の吸収スペクトルは観測されなかった。 アルミニウム基板上に析出した膜（50 mTorr, $10 \mathrm{~W}$, 膜厚 $200 \mathrm{~nm}$ ) の表面構造を SEM によって観測した が，膜の表面には特異性は見られず，表面が非常に平 たんな膜になっているととがわかった。

〈3.4〉 パルス電磁誘導プラズマ CVD による膜析 出 パルス電磁誘導プラズマCVDによって作製し た a-C : H 膜は，高周波の場合とほぼ同じく，黄色 がかった透明色を示した。常温ガラス基板に析出した 膜は，高周波プラズマ中で常温基板に析出された膜の ような亀裂も生じず，またピンセット先端部によって 屯膜損傷は少なく，剥離むないくらいに基板への密着 性が良かった。乙れはパルス電磁誘導放電の電子温度 か瞬間的に $20,000 \mathrm{~K} \sim 50,000 \mathrm{~K}$ （図 7) になってい るために，高周波同㥞の電子による成長膜層の表面加 熱が行われたためによる効果と思われる。また，膜は 基板上に直径 $1 \mathrm{~cm}$ 程度の円状に析出し， $J_{\theta} \times B_{z}$ のピ

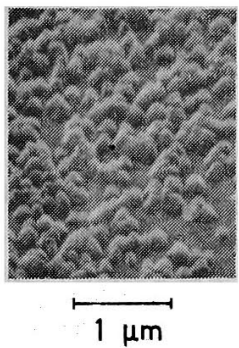

図 9 パルス電磁誘導プラズマ CVD で作製された薄膜の走查電子顕微鏡写真

Fig. 9. Scanning electron micrograph of the thin film prepared by the pulsed inductive plasma CVD.

ンチカがプラズマ柱を半径方向に圧縮している。ての 円状の析出パターンは低圧力においてますます明りょ うになった。磁気ピンチカ $J_{\theta} \times B_{Z}$ は (2) 式を用いる と $-d / d r\left(B z^{2} / 2 \mu_{0}\right)$ となり, 磁気圧力 $B z^{2} / 2 \mu_{0}$ の傾 きによって表現される。低気圧において磁気圧力が 粒子圧力より格段に大きくなり，プラズマの圧縮加熱 が勃果的认なる。 $30 \mathrm{mTorr}$ 程度の封入圧力ではこの 半径方向内向きのピンチ力の最大值は約 $5 \mathrm{~N} / \mathrm{cm}^{3}$ であることが磁気プローブ, 電界プローブの測定から わかった ${ }^{(14)}$ 。析出膜の可視吸収スペクトルから求め た $(\alpha h \nu)^{1 / 2}-E$ の関係を図 8 中に破線で示した。こ の膜は圧力 $50 \mathrm{~m}$ Torr $の$ 条件（放電の繰返し時間約 1 分) で 350 回放電することによって得られたもので， 膜厚は $350 \mathrm{~nm}$ である。図より光学ギャップの值は $1.5 \mathrm{eV}$ であることがわかり，高周波プラズマ CVD による $\mathrm{a}-\mathrm{C}: \mathrm{H}$ 膜特性とは大きな差異は見られない。

図 9 は走査電子顕微鏡写真の例である。コイル中央 部で放電管軸に垂直に置いた常温のアルミニウム基板 上に $50 \mathrm{~m}$ Torr の条件で, 200 回放電によって作製し たものであり，円状析出パターンの周辺部分の写真で ある。 $0.1 \mu \mathrm{m}$ 程度の微粒子が堆積している。円状パ ターンの内部では高周波プラズマ $\mathrm{CVD}$ 膜と同様に表 面が平滑な膜となっていた。前述のようにピンチプラ ズマ柱は既に析出された膜表面に接触し，膜表面を加 熱するととになる。その結果，常温基板に成長した膜 は部分的なグラファイト化や取り込まれた水素の再放 出が行われ，基板をヒータで加熱するのと同じ効果が 生じているものと予想される。

高周波放電により常温基板に析出した膜質につい ては Wagner 氏らによる最近の報告があり ${ }^{(15) ， 46}$ mTorr の圧力では $E_{\text {opt }} \sim 3 \mathrm{eV}$ のポリマー状膜が得ら れている。また Anderson 氏 ${ }^{(12)} は 127^{\circ} \mathrm{C}(400 \mathrm{~K})$ の 基板温度, $0.4 \sim 0.8$ Torr の条件で $E_{\mathrm{opt}} \sim 2.6 \mathrm{eV}$ の 
薄膜を析出しており，てれ以下の温度で作製した膜は 数時間後に基板より永離することを報告している。 本実験においてあ高周波方式により常温基板へ析出し た膜は基板から虽離し，膜質特性は計測できなかっ た。他方，パルス電磁誘導プラズマにより常温基板上 に析出した膜は基板への付着性が良く，高周波方式で 加熱基板へ析出する膜之同程度の光学ギャップ（ 1.5 eV) を有した。このととは $200^{\circ} \mathrm{C}$ 以上では熱的に損 傷，破塄する材料であ，パルス電磁誘導方式を用いれ ば，良質のアモルファスカーボン薄膜析出のための基 板として採用できることを示している。更に，パルス 電磁誘導プラズマによって加熱ガラス基板 $\left(200^{\circ} \mathrm{C}\right)$ 上 に薄膜を堆皘したが (50 mTorr, 300 回放電)，析出 した膜は黒色の不均一，まだらな膜であり，基板温度 加熱のためにグラファイト化が著しくなったものと思 われる。また，乙の析出物質は基板から容易に剥離 し，基板加熱は良椞膜生成のためには必ずしも有效で ないことがわかった。

\section{4. 結論}

パルス電磁誘導放電法と高周波放電法によってメタ ンプラズマを生成し，アモルファスカーボン膜を作製 する実験を行い次のととが明らかになった。

（1） 高周波放電では $p d \approx 1$ Torr $\cdot \mathrm{cm}$ で最小の絶 縁破壊条件になる。 $\mathrm{H} \alpha, \mathrm{H} \beta, \mathrm{H} \gamma$ を用いた分 光測定の結果, 高周波放電プラズマの電子温 度は本実験条件では $12,300 \mathrm{~K} \sim 16,000 \mathrm{~K}$ の 符囲にあることがわかった。

（2）パルス電磁誘導法に上るプラズマは放電初期 には高温の非平衡プラズマであるが，それ以 後 $6,000 \mathrm{~K} \sim 4,000 \mathrm{~K}$ 程度の平衡プラズマに なっていることがわかった。

（3）高周波方式による析出膜の成長速度は $1.0 \sim$ $3 \mathrm{~nm} / \mathrm{min}$ であり，光学ギャップは $1.45 \sim$ $1.64 \mathrm{eV}$ の範囲にあった。パルス䉓磁誘導法 による膜は常温基板に付着性良く堆積され， その光学ギャップは約 $1.5 \mathrm{eV}$ であった。

（4）パルス電磁誘導方式は，高周波法と比校する 之, 特定のエネルギー準位の選択的励起，電 磁压縮作用を受けたパルス高エネルギープラ ズマによる膜表面加熱などの特長を有し，プ ラズマ材料プロセシングの新しい方式として の可能性が示された。
最後に，本実験を行うにあたり大学院生竹下雅信君 (現株式会社日立製作所), 辻公輝技官, 伊元友明技官 の御協力をいただいた。析出膜の SEM，ラマン分光 などの評価について科学技術庁松本精一郎主任研究 官に多大の御助力をいただいた。

また，本研究に対し深い御理解と激励をいただいた 大野 稔博士（日立超 LSI エンジニアリング(株)） に感謝の意を表します。なお，本研究の一部は文部省 科学研究費 (一般研究C) の援助を受りて行われた。

(昭和 61 年 8 月 25 日受付, 同 61 年 12 月 22 日再受 付）

\section{文献}

(1) H.F. Winters: "Dissociation of methane by electron impact", J. Appl. Phys., 63, 3462 (1975)

(2) J. F.M. Aarts, C.I.M. Beenakker \& F. J. DeHeer: "Radiation from $\mathrm{CH}_{4}$ and $\mathrm{C}_{2} \mathrm{H}_{4}$ produced by electron impact", Physica, 53, 32 (1971)

(3) W. Braun, J. R. McNesby \& A. M. Bass: "Flash photolysis of methane in the vacuum ultraviolet. II ", J. Chem. Phys., 46, 2071 (1967)

(4) M.Duval \& A, Theroet: "A comparative study of microwave and radiofrequency plasma polymerization of Benzene", J. Electrochem. Soc., 122, 581 (1975)

(5) K. Kobayashi, N. Mutsukura \& Y. Machi : "Deposition of hard carbon films by rf glow discharge method". $J$. Appl. Phys., 59, 910 (1986)

(6) M. Sokolowski, A. Sokolowska; B. Gokieli, A. Michalski, A. Rusek \& Z. Romanowski : "Reactive pulse plasma crystallization of diamond and diamond-like carbon", $J$. Crystal Growth, 47, 421 (1979)

(7) M. Sokolowski " "Influence of the pulse plasma chemical content on the crystallization of diamond under conditions of its thermodynamic instability", ibid., 54, 519 (1981)

(8) G.I. Babat: "Electrodeless discharges and some allied problems". J. Inst. Elect. Engrs. (London), 94, 27 (1947)

(9) S.V. Dresvin: "Physics and Technology of LowTemperature Plasmas" (Iowa State University, Ames, Lowa, 1977), p. 56.

(10) A. Bubenzer, B. Dischler, G. Brandt \& P. Koidl: "rfplasma deposited amorphous hydrogenated hard carbon thin films: Preparation, properties, and application", J. Appl. Phys. 54, 4590 (1983)

(11) B. Dischler, A. Bubenzer \& P. Koidl: "Hard carbon coating with optical absorption", Appl. Phys. Lett., 42, 636 (1983)

(12) D. A. Anderson: "The electrical and optical properties of amorphous carbon prepared by the glow discharge technique", Philosophical Magazine, 35, 17 (1977)

(13) J. M. Mackowski, R. Pignard, N. Vedovotto, P. Robert \& A. Donnadieu : "Amorphous diamond-like carbon films : Effect of deposition rate on optical and mechanical properties", $J$. Non-Cryst. Solids 7-78, 837 (1985)

(14) K. Ebihara: "Radical electromagnetic energy flow and plasma heating power for theta pinch discharges", $J$. Phys. Soc. Jpn., 48, 958 (1980)

(15). J. Wagner and P. Lautenschlager: "Hard amorphous carbon studied by ellipsometry and photoluminescence", J. Appl. Phys., 59, 2044 (1986) 